\title{
Reanalysis of genotype distributions published in Neurology between 1999 and 2002
}

\author{
István Kocsis, MD, PhD; Barna Vásárhelyi, MD, PhD; András Györffy, VetD; and Balázs Györffy, MD
}

\begin{abstract}
The authors tested 123 genotypes described in 54 papers published in the journal Neurology between 1999 and 2002 to ascertain whether these genotype distributions deviated from Hardy-Weinberg equilibrium (HWE). Unreported deviations from HWE in 19 genotype distributions described in 11 of the papers were discovered. The authors also report additional information that could have been extracted after calculating HWE and conclude that HWE values should be mandatory in population genetic studies published in Neurology.
\end{abstract}

NEUROLOGY 2004;63:357-358

The gene frequencies at a locus in a randomly interbreeding diploid population and population genotype frequencies remain constant from generation to generation if mating is random and if mutation, selection, and migration do not occur. A mathematical formula created by Hardy and Weinberg ${ }^{1-4}$ allows for this equilibrium to be tested in studied populations.

The Hardy-Weinberg law is suitable for testing the hypothesis of panmixia (random mating within a breeding population) and evolutionary stasis. It is a null hypothesis in genetic studies for testing the suitability of the enrolled reference population and for detecting even weak associations between genotype and disease. However, Hardy-Weinberg equilibrium (HWE) is not always calculated and published in papers investigating population genetics, as we found after reviewing a sample of papers published in recent volumes of Neurology.

Subjects and methods. We reanalyzed genotypes described in papers published in Neurology between 1999 and 2002. Enrollment criteria were investigation of biallelic genetic polymorphisms with Mendelian inheritance and case-control study design. We calculated HWE values for each published genotype in each subject group using the Arlequin program (http://anthropologie. unige.ch/arlequin/). ${ }^{6,7}$ The level of significance was set at $p<0.05$.

Results. After recalculating distributions of 123 genotypes described in 54 papers, we found 19 genotypes deviated from HWE (table). In none of the cases did the authors mention that the HWE $p$ value was under 0.05 . Significant deviation from Hardy-Weinberg expectation occurred in either control or investigated populations in three papers, in healthy reference genotypes in four papers, and in diseased genotypes in five papers.

Discussion. Genotype frequencies may deviate significantly from the expected values for several reasons. Deviations should appear in 1 of every 20 genotypes, if the level of significance is set at $p=$ 0.05 . However, regardless of the exact mechanism used to determine deviations, the fact that the distribution of the studied genotype deviates from HWE should be mentioned by authors. Another frequent, although often unreported, cause for deviations is methodologic bias. The applied method might, for example, not allow for adequate discrimination between hetero- and homozygotes, potentially leading to the alteration of genotype distribution. One or more of the model's assumptions may also be incorrect. Nonrandom mating (inbreeding or an allele effect on the mating) or gene flow may be occurring, selection may be operating, or something else evolutionarily interesting could be happening. Deviations could also be the result of a sampling error. The sample size could be too small, it might not be from a single population, or genotypes could have a different likelihood of being included in the sample. ${ }^{5}$ Taking these possibilities into consideration, authors should always calculate $\mathrm{HW}$ values.

We also found articles in which the populations being investigated deviated from HWE, but this fact was unreported. This would appear to discount the associations, or the lack thereof, put forward in several of the papers we sampled in our study. These include the association between the GSTM3 AA genotype and disability in patients with multiple sclerosis and between $A P O E$ promoter $(-219 \mathrm{G} / \mathrm{T})$ and Alzheimer disease (AD) in Finnish populations as well as the lack of an association between NOS3 Glu/Asp polymorphism and ischemic stroke, between sporadic inclusion body myositis and $\operatorname{PrP}$ codon 129 methionine homozygosity, between CST3 + 73 G/A

From the First Department of Pediatrics (Dr. Kocsis) and Second Department of Internal Medicine (Drs. A. Györffy and B. Györffy), Semmelweis University,

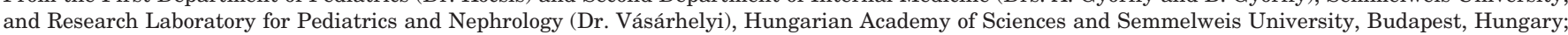
and Charité (Dr. B. Györffy), Institute of Pathology, Humboldt University, Berlin, Germany.

Received September 23, 2003. Accepted in final form March 8, 2004.

Address correspondence and reprint requests to Dr. István Kocsis, First Department of Pediatrics, Semmelweis University, Budapest, Hungary; e-mail: kopist@gyer1.sote.hu 
Table Papers in Neurology between 1999 and 2002 in which deviations from Hardy-Weinberg equilibrium (HWE) were not noted

\begin{tabular}{|c|c|c|c|c|c|c|c|c|c|c|}
\hline \multirow[b]{2}{*}{ Vol: page nos } & \multirow[b]{2}{*}{ Genetic polymorphism } & \multirow{2}{*}{$\begin{array}{c}\text { Affected } \\
\text { population }\end{array}$} & \multicolumn{3}{|c|}{ Reported } & \multirow[b]{2}{*}{$\mathrm{n}$} & \multicolumn{3}{|c|}{ Expected } & \multirow{2}{*}{$\begin{array}{c}\text { HWE } \\
p \text { value }\end{array}$} \\
\hline & & & $A A$ & $A B$ & $B B$ & & $A A$ & $A B$ & $B B$ & \\
\hline $53: 418-420$ & NOS3 gene (Glu/Asp) & Control & 154 & 203 & 36 & 393 & 166 & 179 & 48 & 0.0079 \\
\hline $54: 552-557$ & GSTM3 & Control & 221 & 64 & 15 & 300 & 213 & 79 & 8 & 0.0015 \\
\hline \multirow[t]{4}{*}{$55: 1235$} & \multirow[t]{4}{*}{ Prion protein gene (Met/Val) } & Controls & 156 & 44 & 198 & 398 & 79 & 197 & 122 & 0.0001 \\
\hline & & Controls & 129 & 25 & 146 & 300 & 67 & 149 & 84 & 0.0001 \\
\hline & & Patients & 21 & 1 & 19 & 41 & 11 & 21 & 9 & 0.0001 \\
\hline & & Patients & 14 & 1 & 7 & 22 & 10 & 10 & 2 & 0.0001 \\
\hline 56:1593-1595 & $A C E I / D$ & Patients & 120 & 239 & 74 & 433 & 132 & 214 & 87 & 0.020 \\
\hline \multirow[t]{2}{*}{ 57:337-339 } & CST3-157 G/C & Patients & 140 & 33 & 6 & 179 & 137 & 39 & 3 & 0.0387 \\
\hline & $C S T 3+73$ G/A & Controls & 180 & 40 & 8 & 228 & 175 & 49 & 4 & 0.0091 \\
\hline \multirow[t]{2}{*}{$58: 124-126$} & $D 1.1$ & Controls & 16 & 32 & 42 & 90 & 12 & 41 & 37 & 0.0393 \\
\hline & $D 1.8$ & Controls & 17 & 7 & 5 & 29 & 14 & 12 & 3 & 0.0343 \\
\hline 58:881-884 & Nurr1 7048G7049 & Patients & 162 & 48 & 15 & 225 & 154 & 64 & 7 & 0.0049 \\
\hline 58:1566-1568 & IL-1B $(-511)$ & Controls & 95 & 107 & 15 & 217 & 101 & 94 & 22 & 0.0380 \\
\hline \multirow[t]{4}{*}{$59: 59-66$} & $A P O E$ promoter $(-491)$ & Patients & 94 & 18 & 4 & 116 & 91 & 23 & 2 & 0.0312 \\
\hline & $A P O E$ promoter $(-219)$ & Controls & 67 & 102 & 19 & 188 & 74 & 88 & 26 & 0.0429 \\
\hline & & Patients & 57 & 118 & 100 & 275 & 49 & 134 & 92 & 0.0477 \\
\hline & & Patients & 120 & 361 & 194 & 675 & 134 & 333 & 208 & 0.0444 \\
\hline $59: 724-728$ & $O P R M 1$ & Patients & 193 & 29 & 8 & 230 & 187 & 41 & 2 & 0.0002 \\
\hline $59: 756-758$ & A2M-Ile1000Val & Patients & 61 & 48 & 23 & 132 & 55 & 60 & 17 & 0.0244 \\
\hline
\end{tabular}

polymorphism and $\mathrm{AD}$ in Japanese patients, between dopamine receptor 1.1 or 1.8 and blepharospasm, and between interleukin-1B (-511) polymorphism and $\mathrm{AD}$ (see the table).

We found low HWE values in patient populations in studies investigating $A C E D$ allele in dementia, Nurr1 gene in subjects with Parkinson disease, $A P O E$ promoter $-491 A A$ genotype in $\mathrm{AD}$ in Spanish subjects, $A P O E$ promoter - $219 T T$ genotype in $\mathrm{AD}$ in English and French subjects, $\mu$-opioid receptor subunit gene -172 TT genotype in subjects with idiopathic generalized epilepsy $\alpha_{2}$-macroglobulin, and Val1000 allele in subjects with AD. Although the authors found significant associations in these studies, the deviations of genotype distribution in the patient populations would have been further evidence for the observed associations. This was also the case when the authors of a paper from the sample found no association between the cystatin $\mathrm{C}$ promoter and increased risk of $\mathrm{AD}$. In spite of the lack of significant difference between allele or genotype frequency of control and patient groups, there could be some association between this genetic variant and increased risk for the disease, according to the low HWE value.

These cases suggest that authors should always calculate HWE and consider the results when evaluating population genetic studies investigating the significance of a genetic polymorphism of Mendelian inheritance in human disease.

\section{References}

1. Hardy GH. Mendelian proportions in a mixed population. Science 1908; 28:49-50.

2. Weinberg W. Über den Nachweis der Vererbung beim Menchen. Jahresh Verein f Vaterl Naturk in Wüttemberg 1908;64:368-382.

3. Roughgarden J. Theory of population genetics and evolutionary ecology. Englewood Cliffs: Prentice Hall, 1996.

4. Stern C. The Hardy-Weinberg law. Science 1943;97:137-138.

5. Hedrick PW. Genetics of populations. New York: Van Nostrand Reinhold, 1983.

6. Schneider S, Roessli D, Excoffier L. Arlequin ver. 2.000: a software for population genetics data analysis. University of Geneva, Switzerland: Genetics and Biometry Laboratory, 2000.

7. Guo SW, Thompson EA. Performing the exact test of Hardy-Weinberg proportion for multiple alleles. Biometrics 1992;48:361-372. 


\section{Neurology}

Reanalysis of genotype distributions published in Neurology between 1999 and 2002

István Kocsis, Barna Vásárhelyi, András Györffy, et al.

Neurology 2004;63;357-358

DOI 10.1212/01.WNL.0000130248.66159.92

This information is current as of July 26, 2004

\section{Updated Information \&} Services

References

Citations

Subspecialty Collections

Permissions \& Licensing

Reprints including high resolution figures, can be found at: http://n.neurology.org/content/63/2/357.full

This article cites 4 articles, 2 of which you can access for free at: http://n.neurology.org/content/63/2/357.full\#ref-list-1

This article has been cited by 2 HighWire-hosted articles: http://n.neurology.org/content/63/2/357.full\#\#otherarticles

This article, along with others on similar topics, appears in the following collection(s):

\section{All Genetics}

http://n.neurology.org/cgi/collection/all_genetics

Information about reproducing this article in parts (figures,tables) or in its entirety can be found online at:

http://www.neurology.org/about/about_the_journal\#permissions

Information about ordering reprints can be found online:

http://n.neurology.org/subscribers/advertise

Neurology ${ }^{\circledR}$ is the official journal of the American Academy of Neurology. Published continuously since 1951, it is now a weekly with 48 issues per year. Copyright . All rights reserved. Print ISSN: 0028-3878. Online ISSN: 1526-632X.

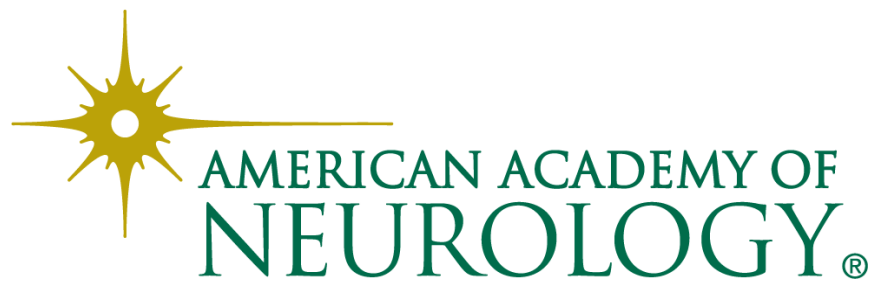

